\title{
Relation of Architectural Function and Form of Mosque Jami 'Al Mukarromah Kampung Bandan North Jakarta
}

\author{
Ashadi Ashadi ${ }^{1}$, Anisa Anisa ${ }^{2}$ \\ ${ }^{1}$ Department of Architecture, Universitas Muhammadiyah Jakarta, Indonesia \\ ${ }^{2}$ Department of Architecture, Universitas Muhammadiyah Jakarta, Indonesia \\ ashadi@ftumj.ac.id
}

\begin{abstract}
There are two essential aspects of architecture, namely function, and form. Function is an activity that must be accommodated in an architectural form (space). This research was the exploration of function and form and the relation between them in the architecture of Masjid Jami 'Al Mukarromah Kampung Bandan. The purpose of the research was to get a conclusion of the relation between activity in the mosque and its architectural form. From the interpretation of this relation was expected to be revealed its meaning. This research used the descriptive, interpretive method. Field data collection was done by observing the activities in Masjid Jami 'Al Mukarromah and observing the architectural form of the mosque associated with the activities undertaken in the mosque. In addition to observation of the object of study, also conducted interviews with the primary source who was direct descendants of Habib Abdurahman bin Alwi Asy-Syatiri named Habib Alwi bin Ali As-Syatiri. Besides, interviews were also conducted to marbot Masjid Jami 'Al Mukarromah Kampung Bandan. The results of this study showed two conditions: first, there was a relation between function and form, thus raising the meaning of functional architecture; secondly, there was no relation between function and form, especially with regard to the function of prayer and pilgrimages, whose containers (architectural forms) overlap, giving rise to syncretic architectural significance.
\end{abstract}

(C) 2019 IJBESR. All rights reserved.

Keywords: Relation, Function, Form, Meaning, Architecture.

\section{Introduction}

Activities or functions in architecture will affect the formation of a container called space. In the period of modern architecture, so-called functions are activities carried out by humans in three-dimensional space [1]. A container in the form of a three-dimensional space that holds the activity is called a form [2].

In this study, what is meant by activities are all things done by building users. The object taken in this study is one of the historic mosques, the Masjid Jami 'Al Mukarromah Kampung Bandan, North Jakarta, formerly the Kampung Bandan mosque. Often also referred to as the Kramat (Keramat) Kampung Bandan mosque because of Habib's tomb in the mosque. The premise of this research is that the activities or functions carried out at this mosque have a relation to the form of the mosque Jami' Al Mukarromah Mosque is one of the mosques that are protected by law because they are objects of cultural heritage.

In addition to the Jami' Al Mukarromah mosque in Kampung Bandan, there are still several other historical mosques in Jakarta, namely Luar Batang mosque, Mangga Dua mosque, AlMansyur mosque, Annawir mosque, Kampung Baru mosque, Angke mosque, and Tambora mosque. The uniqueness of the Jami' Al Mukarromah mosque compared to other historic mosques, 
namely, firstly, its location is right on the edge of the busy Lodan road, and secondly, there is a Habib tomb in this mosque which is the destination of pilgrimage. Kampung Bandan has an area of 22.1 ha based on DKI Jakarta Regulation No. 1 of 2014 annex III-3 concerning Spatial Detail Plan and Zoning Regulations [3]

Based on interviews obtained data that the Ancol village is divided into $7 \mathrm{RW}$. Kampung Bandan is located in the area of RW 2, which consists of 15 RT with around 2090 households. The population is 4277 male and 2988 female. Activities that take place at the Jami' Al Mukarromah mosque in Kampung Bandan can be observed based on activities carried out daily, weekly, monthly, and annually. For example, the activities of five daily prayers, weekly recitation, bazaar, twoday Eid and Eid al-Adha prayers, celebrations of Islamic holidays, Haul, Maulidid and pilgrimage of Habib pilgrimage.

The preliminary research that has been carried out is titled Residential Arrangement Model Around Historic Buildings in the context of increasing the Potential of Tourism Areas, Case of Residential Study around the Luar Batang Mosque. The results of this study have been published in DOAJ indexed national journals, IJRG International journals, and were disseminated at national seminars.

Based on this background, this study aims to: (1) identify and know the activities carried out in the mosque; and (2) identifying and understanding the architectural form of the mosque; and (3) correlating user activities with the form of the mosque. From the results of the interpretation of the relationship between function and form, it is expected to reveal the meaning of the architecture of the Masjid Jami' Al Mukarromah Kampung Bandan, North Jakarta.
The architecture of the Masjid Jami 'Al Mukarromah Kampung Bandan is a cultural product that contains tangible and intangible elements, so in this study an interpretive descriptive approach will be used. The descriptive approach aims to describe the reality of the existence of the mosque and the socio-cultural reality that exists in the Muslim community of mosque users as a factual entity. And the interpretive approach is a process of the meaning of a problematic value that is in the object of research through the interpretation of the relations of activities or functions and forms of mosque architecture.

\section{Material and Methods}

This study uses an interpretive descriptive method. Field data collection is done by first, observing the subject of study, namely by observing the activities carried out at the Masjid Jami' Al Mukarromah Kampung Bandan. Second, observing the form of mosque architecture associated with activities carried out at the mosque. The forms observed include prayer rooms, pilgrimage rooms, and porches. In addition to observation, interviews are also essential to do. Interview with the main resource person who is a direct descendant of Habib Abdurahman bin Alwi Asy-Syathri named Habib Alwi bin Ali AsSyatiri. Besides, interviews were also conducted with the marbot mosque of Jami 'Al Mukarromah Kampung Bandan.

In order to achieve the research objectives, the following steps are taken: (1) recording and describing the activities carried out in the mosque; (2) record and describe the architectural form of the mosque; (3) linking or correlating the activities carried out in the mosque with the form of mosque architecture; and (4) interpreting these relations to reveal meaning. These steps also become an essential part of the research framework developed. (Figure 1). 


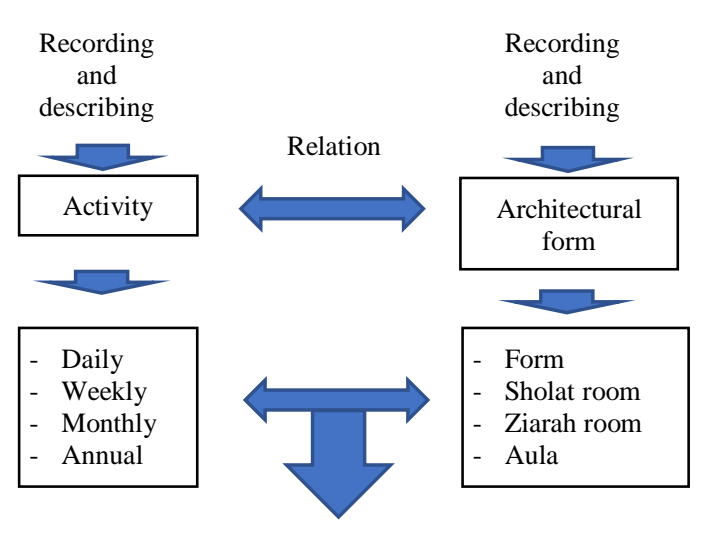

Interpretation

Figure 1: Research Framework

\section{Results and Discussions}

\subsection{Theoretical Study: The Relationship between Function-Form-Meaning}

In the field of architecture, studies on function and form have been done quite a lot. Modern architectural figures, led by Sullivan, used a reductionist approach in looking at architecture. The rhetorical form follow function (form follows the function) becomes the basis for designing modern architecture. The assumption is that architecture, as something intentionally made, is a purely functional manifestation. Since the 1970s, understandings of architectural conceptions involving cultural dimensions were born. Amos Rapoport in the Human Aspects of Urban Form, explained, architectural space is not merely dealing with three-dimensional physical space, because, at different times and contexts, a person is dealing with a different kind of space [4].

Christian Norberg-Schultz conveys four architectural functions: physical control, functional frame, social milieu, and cultural symbolization [5]. Rob Krier [6] discusses the relationship between function and form in detail. Function is a fundamental starting point for all forms of architecture. Function, construction, and form are equally important factors that together determine architecture.
Furthermore, Krier states that architecture must provide physical protection from environmental influences, create a framework for activities; above all, architecture must express symbolic and ethical values.

The relation of function-form-meaning is one of the essential themes in the study of architecture. It was started by Marcus Vitruvius Pollio (around the first century BC), who stated that all buildings must be built with reference to durability (firmitas), convenience (utility), and beauty (venustas) [7] (Figure 2a).

The Vitruvius Trium was then tested by David Smith Capon. Capon concluded, there are six categories in the principles of architecture (principles of good architecture), which are grouped into primary and secondary categories, namely: function, form, meaning as primary categories, and context, construction, spirit as secondary categories. [8]. (Figure 2b).

Purnama Salura and Bachtiar Fauzy developed the concept of the function-form-meaning rotation. Every architectural design product must give priority to the elements of functionform-meaning. These three elements form a triangle shape, which is always in a state of change (spinning) [9]. This concept shows that architecture is ever-changing. (Figure 2c).

In this research, architecture is understood as a relation of aspects of function-form-meaning in the construction of a triangle which is always in a state related to one another. The relationship of function-form-meaning in architecture is used as a theoretical approach to understanding the architectural meaning of the Masjid Jami 'Al Mukarromah Kampung Bandan, North Jakarta. (Figure 2d). 


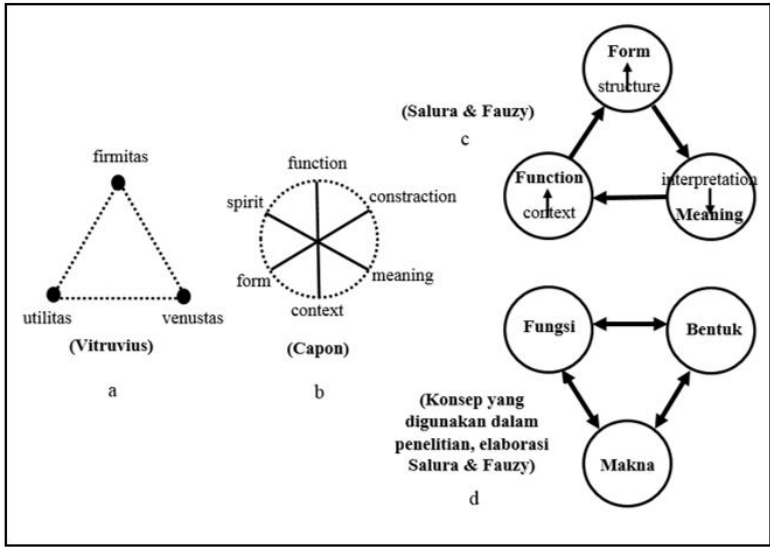

Figure 2. Diagram of the concept of relations of aspects in architecture according to Vitruvius, Capon,Salura and Fauzy, and concepts used in research.

\subsection{Kampung Bandan}

Kampung Bandan is one of the urban villages in the Ancol area, Pademangan District, North Jakarta. This village is close to the Sunda Kelapa Harbor. Based on historical book records, the origin of why this area is called Kampung Bandan is from the word "Banda" which is the name of the island in the Maluku region. During the Dutch Colonial Government in 1621, this area was used as a shelter for slaves from Maluku. At that time many slaves were accommodated in Batavia, besides originating from Maluku, also from regions of Sumatra, Java, Bali, Manggarai, Buton, Sulawesi, Sumbawa, Mandar, and Papua. [10] [11]

In addition, Kampung Bandan is also a change of speech from the word "pandan." In the past in this village many pandanus trees grew, so people called it the name of Kampong Pandan, which changed to Kampung Bandan. Achmad Ruchiat, in his book Origin of Place Names in Jakarta, writes Kampung Bandan or Kampung Banda or Kampung Pandan is a small colony that is grouped by the VOC in a place. Almost all the residents of Kampung Bandan came from Banda and were taken to Batavia as slaves. [12].
Whereas Heuken, in his book Historic Old Mosques in Jakarta. In the book, it is mentioned that there is an old mosque called Al-Mukaromah in which there is an ancient tomb typical of the Banda people. [13]. Kampung Bandan then grew to become a dense and slums settlement until now. Kampung Bandan has an area of 6.3 hectares and is bordered by Jalan Lodan Raya and a toll road on the south side and the settlement of Ancol Village which borders Sunda Kelapa Harbor on the north side. The existence of Kampung Bandan is unique because it is in a modern environment; however, the face and culture of the village remain. Physically, the rooms in it show the character of the village that still survive in the midst of the crush of the power of metropolitan space. The village of Bandan, which is inhabited by around 100 family heads, works as a motorcycle taxi driver, laborer, employee or food trader. Within this area, Kampung Bandan has a historic mosque which is the main attraction of the area as a place of pilgrimage named Masjid Jami' Al Mukaromah Kampung Bandan. [14].

\subsection{Masjid Jami 'Al Mukarromah Kampung Bandan}

Al-Mukarromah Mosque is an old mosque in Jakarta that was built in the 18th century. In Arabic, the name of this mosque has a noble or glorified meaning. At first, it was called Kampung Besar Mosque [15]. The Masjid Jami 'Al Mukarromah Kampung Bandan was first built as a small mosque near two graves of the Great 'ulama' of Batavia by Habib Abdul Rachman bin Alwi As Syatiri in 1879. He died in 1908 and his son Habib Alwi bin Abdul Rachman bin Alwi As-Syatiri then build the mosque as a mosque. 


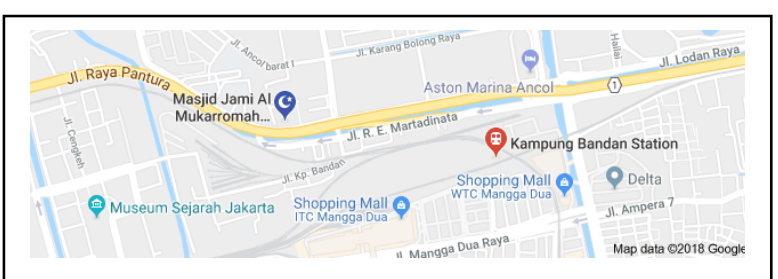

Figure 3. Location of the Jami 'AlMukarromah mosque Source: Google Map, 2018

The history of the construction of this mosque is unique. Habib Abdurrahman bin Alwi AsySyahtiri was a merchant who on one occasion around 1874, visited the residence of Habib Abdullah bin Muhsin Al-Attas in Empang, Bogor. Initially, Habib Abdurrahman only intended to complain about his trading business problems. But, then Habib Abdullah told him to explore the graves of 2 large ulama in Batavia. If found, Habib Abdullah advised Habib Abdurrahman to maintain and establish a place of worship near the tomb. (Results of an interview with Habib Alwi bin Ali AsSyatiri descended from Habib Alwi bin Abdul Rachman bin Alwi As-Syatiri, 2018).

In the Jami 'Al Mukarromah Mosque in Bandan Village there are three tombs of great scholars, Habib Mohammad Bin Umar AlQudsi (died on 23 Muharram 1118 H), Habib Ali Bin Abdurrahman Ba'Alawi (died 15 Ramadhan 1122 H), and Habib Abdurrahman Bin Alwi Asy-Syatiri (died 18 Muharam 1326 $\mathrm{H}$ ), founder of the mosque. These three graves are the oldest ones in Jakarta. Meanwhile, another tomb was also there, the tomb of Habib Ali Bin Alwi bin Abdurrahman AsySyatiri who died on Friday, August 13, 2010.

In 1947, this building was expanded into a mosque that could accommodate many worshipers for worship and pilgrims tomb. This mosque became a historical signification for this village which underwent renovation and expansion in 1972 by the Jakarta Museum and History Department and is still maintained today. Based on Article 1 number 1 of Law Number 11 Year 2010 Concerning Cultural
Preservation states that, "Cultural Preservation is a material cultural heritage in the form of Cultural Preservation Objects, Cultural Preservation Buildings, Cultural Preservation Structures, Cultural Preservation Sites, Cultural Preservation Areas on land / or in water that needs to be preserved because it has important values for history, science, education, religion, and / or culture through the process of stipulation.

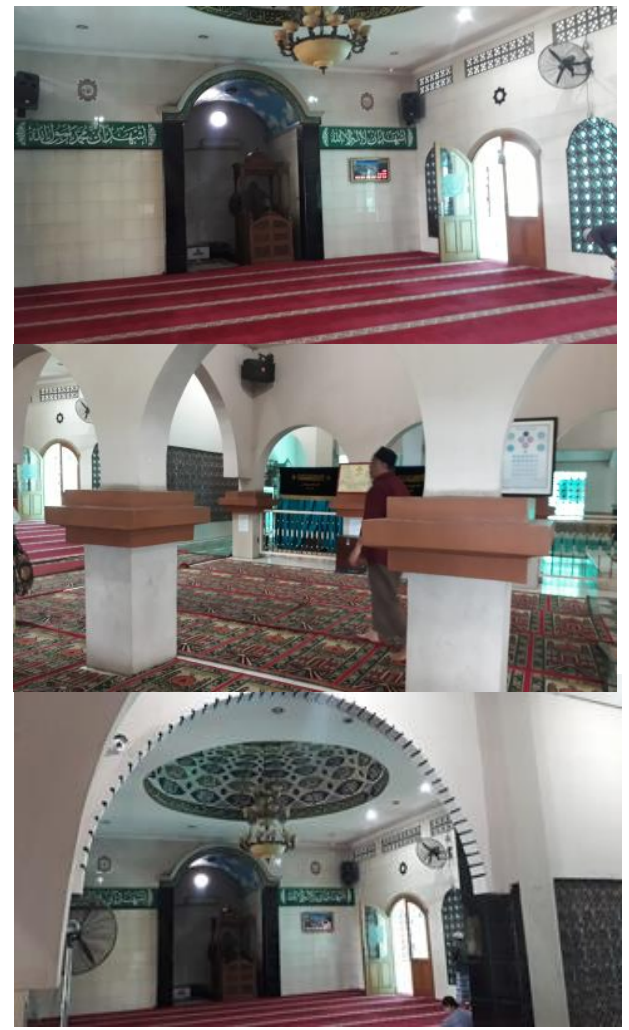

Figure 4. Space in Masjid Jami 'AlMukarromah Source: Personal Documentation, 2018

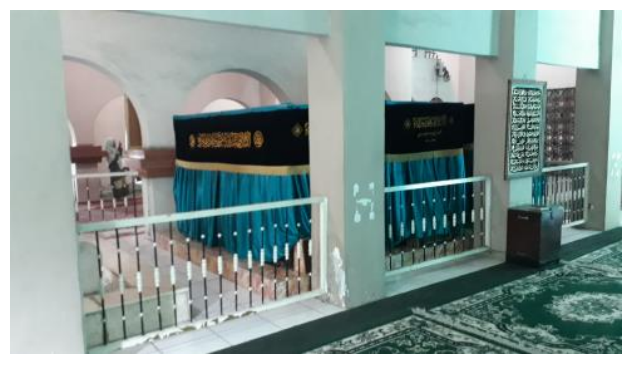

Figure 4. Tomb of Habib at Masjid Jami 'AlMukarromah

Source: Personal Documentation, 2018 
3.4. Recording and Describing Activities at the Jami 'Al Mukarromah Mosque

Recording and describing activities at the Jami' Al Mukarromah Mosque includes daily, weekly, monthly, and yearly activities. Daily activities were observed, namely:

(1) Five daily obligatory prayers in congregation, and

(2) Pilgrimage to the tomb of Habib Mohammad bin Umar Al-Qudsi, Habib Ali bin Abdurrahman Ba' Alwi, and Habib Abdurahman bin Alwi Asy-Syathiri in the mosque.

Inside the mosque, the maximum congregation capacity is 1000 people. And even then use the main prayer room, the side of the tomb, side hall and back hall. The area called the hall is a building that extends the mosque to the rear and side which have no walls. When the congregational prayer takes place five times, the full space is only the main prayer room, which measures about $100 \mathrm{~m} 2$. Except for evening prayers on Friday nights, pilgrims can be more. Habib tomb pilgrimage activities take place every day. Crowds of pilgrims usually arrive on Sundays, red dates and Friday nights. Based on an interview with Habib Alwi, it was informed that the Sya'ban Month was the busiest month for pilgrims to come. In one day it reaches 30 pilgrim buses. The origin of the pilgrims is varied, ranging from Jakarta, Depok, Tangerang, Bekasi, West Java, Central Java, East Java, even from the island of Sumatra.

Weekly activities at the Masjid Jami' AlMukarromah Kampung Bandan include:

(1) Friday prayers;

(2) Pilgrimage to the tomb on Friday nights;

(3) Monday night market (bazaar); and

(4) Weekly Recognition on Friday nights, Monday nights, and Thursday nights.

Friday prayer (Sholat Jum' at) was attended by around 2000-2500 Jamaah. Because of the capacity of this mosque of 1000 worshipers, the Friday prayer reached the hall, the 'Yayasan' terrace, even to the Lodan street. The number of pilgrims accommodated in the mosque is only half of the total number of pilgrims. Weekly pilgrimage activities are pilgrimages that are usually carried out on holidays (Sunday) or Friday nights. On Friday nights after the evening prayer, many pilgrims also came. The pilgrims sometimes rested in the hall and remained in the mosque until dawn. Pilgrimage on weekends or public holidays can reach 10 buses.

Weekly virtual thing other enliven area mosque is of the bazaar ) held every night Monday. Stalls selling is ready after time ashar. Venues being used to the bazaar is track road that is in front of the mosque. The merchants are not allowed trading in the area mosque. They sell on the sidewalk and the slow. Goods sold various starting from the clothes, sandals, praying equipment, a piece of furniture the kitchen, etc. These traders are derived from West Java, Tangerang, and Bogor. Besides selling near a mosque Jami' Al Mukarromah, they are also trading at another place in the bazaar as in mosque Masjid Luar Batang, Empang Bogor, Kwitang, Condet, Pekojan, etc. These traders are also later who will enliven the area around masjid Jami' AlMukarromah when there are a haul, a maulid, and occasions a big day Islamic other. Weekly recitation conducted in the main prayer, mosque with the total number of pilgrims 200 people around Discussed the various. Recitation On malam jum'at with reading yasin ( yasinan ), recitation recitation fiqh, on monday night delivered by habib alwi, and thursday is the pengajian yasinan with yayasan. Recitation was conducted after evening prayer. 

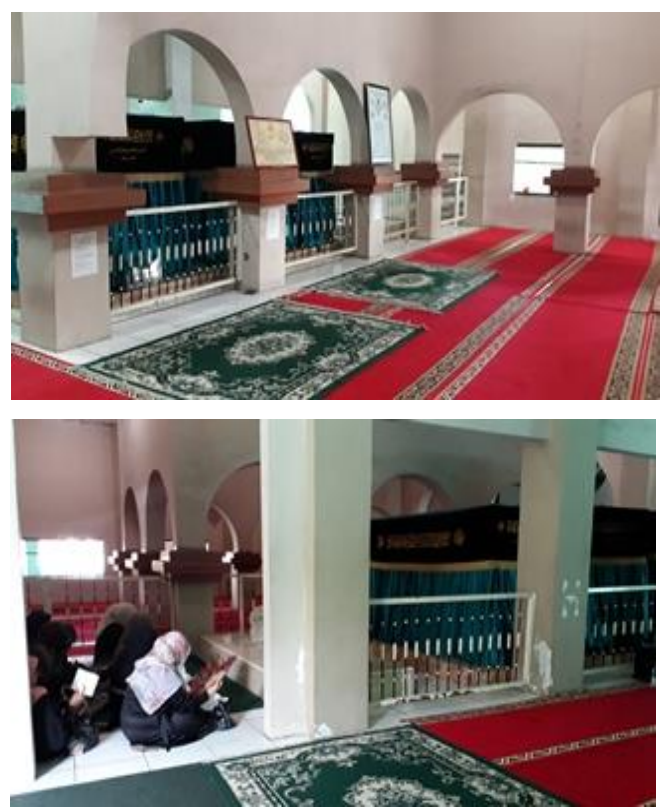

Figure 6. The Main Prayer Room (up) and the pilgrimage room which are used for prayer (down)

Source: Personal Documentation, 2018

There is no monthly activity in masjid Jami' Al mukarromah. It is equal to the Luar Batang mosque there is no monthly activity. Activity is usually on sacred and historical places as mosques Walisanga every month ( 35 precisely the java ), based on the market which falls on Friday night Kliwon or partially Legi, the mosque on Friday pilgrims of more numerous than usual or Friday night regular [16] [17].

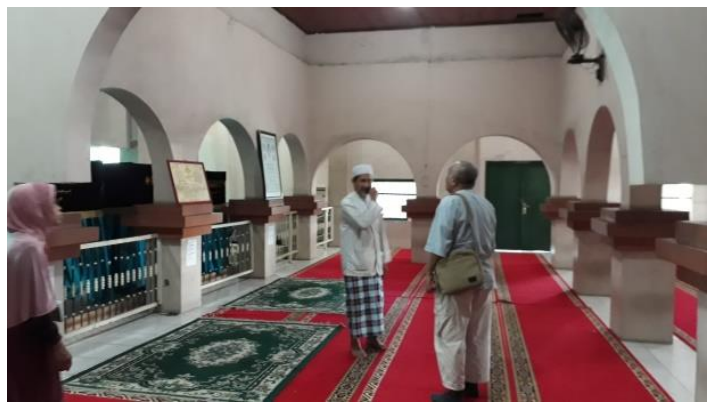

Figure 7. The area provided for pilgrimage, the green carpet becomes a sitting and praying area Source: Personal Documentation, 2018
Annual activity masjid Jami' Al Mukarromah:

1) tarawih in Ramadhan month, prayer Idul Fitri and Idul Adha;

2) Haul Habib during Ramadan, haul Habib and a maulid prophet,

3) iftar.

Based on information from Habib Alwi, all the number of pilgrims at the crowded mosque in early of Ramadan, fulfilling mosque. Pilgrims most crowded around 2000 pilgrims. Those pilgrims meet mosque, to passage a hall and $\mathrm{Jl}$ Sidewalks and the slow lane on Jl Lodan. Pilgrims eid prayer 5000, approximately one pilgrim attend mosque, the even up toward the bridge. Haul for three Habib did two times a year and during Ramadan exactly 12 Ramadhan. Haul Habib who being implemented together with a maulid followed by 5000 pilgrims, and thus during eid. While Habib haul that meets on Ramadan 2000-2500 pilgrims.

They are attended by around people activities when haul Ramadan applied to them until after the prayer Ashar broke up about 10-11 night. Series of events haul Ramadan covering prayer Ashar bow followed by a group meeting and the reading sholawat. When west there reverberate, to prayer the pilgrims open along with takjil and maghrib prayer. After Maghrib prayer only then did the show eat together and take a break while waiting. Late evening After prayers late evening then continued the event the core haul which is the reading manaqib and pilgrimage with tomb after the event the core done and continued with tarawih and close. Lecture during ramadan, this mosque has also made open fast together which is followed by the pilgrims and the surrounding community. Open together in doing in the hall the mosque and a porch Yayasan Almukarromah. 
3.5. Recording and Describing the Architectural Form of the Mosque

Recording and describing the mosque's architectural form includes the scope of the mosque, namely the roof, walls, and floor. Based on interviews with Habib Alwi, information was obtained that the mosque had been renovated three times but did not change the original form. Renovations only expand the mosque area to accommodate an increasing number of pilgrims and pilgrims.

Besides, the renovation was also carried out because of seawater rob in this mosque area. When rob happens, then water will enter this mosque. Elevation of the floor carried out in conjunction with renovation and expansion of the mosque. The form of the first mosque can still be seen today. The form of the first mosque is often called the Nine Pillars, because of the Nine Pillars or columns that support the roof. This mosque is right next to Habib's grave. Formerly the mosque with nine pillars was roofed flat. It was only in 1947 that the roof was replaced with stacking or overlapping.

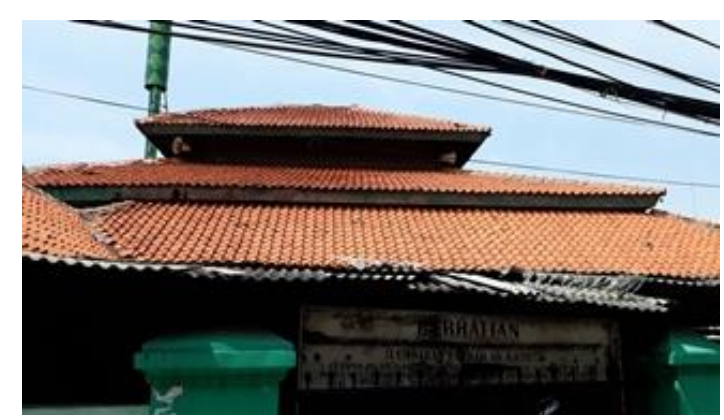

Figure 8. Pilar Sembilan and Tumpang (overlapping) Source : Personal Documentation, 2018

To the frontward expansion, the main prayer room measuring about $100 \mathrm{~m} 2$ and a roofed dome and arches are added to the top of the window door. This was done to make a different design so that the original part of the mosque could be known by extension.
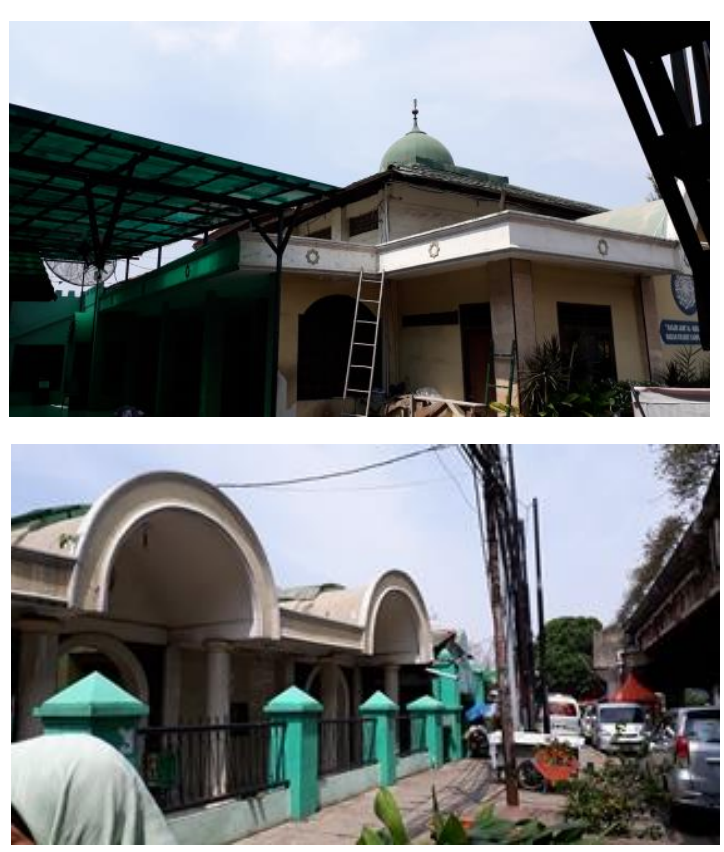

Figure 9. The roof of the main hall of the mosque (up) and visible mosque from Jalan Lodan Raya (down) Source: Personal Documentation, 2018

Expansion is also done on the sides and back of the tomb. The side of the tomb was expanded to provide sufficient space for pilgrims as well as a place of prayer for female worshipers. The expansion of the back of the tomb and the outside which is often called the hall or foyer is actually a kind of terrace of the mosque which is used as a place of prayer and a place to accommodate the activities of pilgrims and pilgrims when the Nine Pillars and the main prayer room are fully used by pilgrims. The hall or porch is quite large, which is around $300 \mathrm{~m} 2$.

\subsection{Relation and Interpretation}

The relation and interpretation section is the final part of the analysis, namely the relation between activities carried out in the mosque (daily, weekly, yearly) and the architectural form of the Jami 'Al Mukarromah Mosque. From the recording and description above, it can be explained the relations that occur. Daily activities related to the form of the mosque; it is evident that the expansion of the mosque 
continues to be carried out to accommodate pilgrims and pilgrims who come every day. More specifically, the area adjacent to the tomb is an important area so that the expansion or renovation of the mosque does not change the original form, which is often called the Nine Pillars. Including the shape of the roof overlapping also related to this relationship.

The mosque's weekly activities in the form of Friday prayer, recitation and bazaar are more widely used by the local community and are not related to the form of the mosque. However, weekly activities in the form of pilgrimage time for holidays or evenings are related to the architecture of the mosque. The annual function of the mosque in the form of Tarawih prayer, Eid al-Fitr and Eid al-Adha, has no relation with the architectural form of the mosque. But for annual activities in the form of haul Habib, the months of Ramadan and haul-maulid are related to the architecture of the mosque. This relationship is shown by the division of the mosque into the main area during haul activities and architecturally shown on the roof.

The relation between function and form shows that the Masjid Jami' Al Mukarromah is a functional architectural work. But on the other hand, the absence of relations shows that there also occurs a mixture of functions which in anthropology are called syncretism. This syncretism occurs because of the mixing of functions or activities between prayer and pilgrimage activities in the mosque. The separation of prayer rooms and pilgrimage rooms that are not massive (do not use massive separation walls) are the cause of this mixture of activities. The meaning of syncretism is more prominent than the functional meaning.

Historical buildings, in this case, the mosque which is equipped with a tomb, usually will be an icon of an area. In other words, the historic mosque of Jami' Al Mukarromah Kampung Bandan in the presence of Habib's tomb can be a place in the area. This is in line with the Holy Mosque-Tomb-Tower complex, which is a place in the Old Holy City area because it is not only of historical value but also of cultural and architectural value. [18]

\section{Conclusion}

Based on the recording and description, which are then correlated and interpreted, the following conclusions can be obtained:

(1) Activities at the Jami' Al Mukarromah mosque include daily, weekly, and annual activities. Daily activities including praying in congregation five times and tomb pilgrimage. Weekly activities include Friday prayers, weekly recitation, weekly pilgrimage, and Monday night bazaars. Annual activities include tarawih prayer, Eid al-Fitr, Eid alAdha, open together, haul-Ramadhan and haul-Maulid. All daily, weekly and annual activities use the mosque as the main place, except the bazaar which is located on the sidewalk in front of the mosque.

(2) The architectural form of the mosque that can be observed includes the top scopes (roof), bottom (floor), and side (wall). The top scopes are divided into 2 forms, the form of overlapping roof covering the original mosque building (Pillar Nine) and the shape of the dome roof that covers the main prayer room at this time. The lower scope (floor) is closely related to the condition of this mosque, which was previously lower than the road so that when there is a tidal wave, water will enter the mosque. After the filling activity happened to avoid the tomb, then the form of the curves next to the original mosque was influenced by the low impression of the window.

(3) There is a relation between activities and forms, showing that the architecture of the Masjid Jami' Al Mukarromah is a functional architectural work. (4) The absence of a relationship between activity and form, 
especially related to pilgrimage activities in the mosque at certain times, or vice versa prayer activities in the tomb, shows that the architecture of the Masjid Jami' Al Mukarromah is a syncretic work of architecture. Even for the Masjid Jami' Al Mukarromah, the meaning of syncretic architecture is more prominent than the meaning of functional architecture.

\section{References}

[1] Heynen, Hilde. (1999). Architecture and Modernity. Massachusets: MIT Press.

[2] Ashadi; Anisa; Nur'aini, Ratna Dewi. (2017a). Fungsi Masjid Bersejarah Luar Batang, Jakarta Utara dan Pengaruhnya terhadap Pola Permukiman di Sekitarnya. Jurnal Arsitektur NALARs Volume 16 No 2 Juli 2017.

https://doi.org/10.24853/nalars.16.2.169-178

[3] Anonim. 2014. Peraturan DKI Jakarta No 1 tahun 2014 Lampiran III-3 tentang Rencana Detail Tata Ruang dan Peraturan Zonasi

[4] Rapoport, Amos.(1977). Human Aspects of Urban Form. Oxford, Toronto: Pergamon Press.

[5] Norberg-Shulz, Christian (1965). Intention in Architecture. Massachusetts : The M.I.T. Press.

[6] Krier, Rob (2001). Komposisi Arsitektur. Jakarta: Penerbit Erlangga.

[7] Morgan, Morris Hicky (1914). VITRUVIUS: The Ten Books on Arcitecture. Cambridge: Harvard University Press.

[8] Capon, David Smith (1999). The Vitruvian Fallacy: Architectural Theory Volume One. New York: John Willey \& Sons.

[9] Salura, Purnama; Fauzy, Bachtiar (2012). The Everrotating Aspects of Function-Form-Meaning in Architecture. Journal of Basic and Applied Scientific Research. TextRoad Publication, 2(7)7086-7090.

[10] Kanumoyoso, Bondan (2011). Beyond the City Wall. Society and Economic Development in the Ommelanden of Batavia, 1684-1740. Dissertation. De Universiteit Leiden.

[11]Permana, Agus; Mawardi (2017). Habaib in Batavia in the $17^{\text {th }}$ Century. A Study on the Roles of Habaib in the Process of Islamization and Islamic Preaching. Tawarih. International Journal for Historical Studies, 9 (1) October 2017: 23-32.

[12] Ruchiat, Rachmat. (2018). Asal usul nama tempat di Jakarta. (edisi revisi) Jakarta: Komunitas Bambu.

[13] Heuken, SJ, Adolf. (2003). Masjid-masjid tua di Jakarta. Jakarta: Yayasan Cipta Loka Caraka.

[14] Makhmud, Desi Fatmala; Nurhasanah, Fitria; Utami, Indah Ulfia; Khansha, Syifa; Radnawati, Daisy; Syahadat, Ray March (2017). Mewujudkan Kampung Bandan sebagai Kampung Kota Berkelanjutan Menggunakan Pendekatan Asian New Urbanism. Vitruvian Jurnal Arsitektur, Bangunan \& Lingkungan Vol. 6 No. 3 Juni 2017: 91-100.

[15] Widya, Katarina (2012). Studi Bentuk dan Elemen Arsitektur Masjid di Jakarta dari Abad 18 - Abad 20. Jurnal Comtech Vol. 3 No. 2 Desember 2012: 917 927.

[16] Ashadi. (2016). Makna Sinkretisme Bentuk pada Arsitektur Masjid-masjid Walisongo. Disertasi. Program Studi Doktor Arsitektur Sekolah Pascasarjana Universitas Parahyangan.

[17] Ashadi; Anisa; Nur'aini, Ratna Dewi. (2017b). Function, Form, and Meaning of Ritual and Market in Historical Site of Kampung Luar Batang Jakarta Indonesia. International Journal of Research Granthaalayah Vol. 5 (Iss.10): October 2017: 169178.

[18] Anisa. (2008). Studi Awal Pola Ruang Kawasan Menara Kudus. Jurnal Arsitektur NALARs Volume 7 Nomor 1 Januari 2008. 